Global Journal of Human Resource Management

Vol.8, No.1, pp.20-45, February 2020

Published by $E C R T D-U K$

Print ISSN: 2053-5686(Print), Online ISSN: 2053-5694(Online)

\title{
MODERATING/MEDIATING EFFECTS OF HRM PRACTICES IN ORGANIZATIONAL JUSTICE ON INNOVATIVE WORK BEHAVIOUR AMONG HOTEL INDUSTRY OF PAKISTAN: CASE STUDY OF KARACHI
}

\author{
Uzma Ismail \\ Department of Management Sciences, Hajvery University, Lahore, Pakistan \\ uzmaismai157@yahoo.com
}

\begin{abstract}
Innovative work behavior and Human Resource Management practices (HRMPs) are affected by organizational justice. These play a very important role in the hotel industry. The paper seeks to explore the moderating and mediating effects of Human Resource Management practices (HRMPs) in organizational justice on innovative work behavior among the hotel industry of Karachi, Pakistan. Furthermore, it is to enhance the understanding of the antecedents of Organizational Justice (OJ), Innovative Work Behavior and Human Resource Management Practices (HRMPs). Quantitative methodology is adopted for this study. A survey questionnaire was adopted to collect data from approximately 52 employees of Hotels located in Karachi. Out of 52 questionnaires distributed, 50 were collected thus; the approximate response rate was about 96\%. The analysis is based on responses retrieved from the middle and top-level management of selected hotels. It was observed that there is a significant relationship between organizational justices and innovative work behavior. It was also observed that HRMPs were not moderating significantly between organization justice and innovative work behavior but the mediation of HRMPs was found between them. It is predicted that the findings of this study will be useful not only for the hotels and their employees but also for future research scholars.
\end{abstract}

KEYWORDS: organizational justices, innovative work behaviors, human resource management practices.

\section{INTRODUCTION}

Hospitality industry is among the fastest growing and critically challenging industries in the world (Korczynski, 2002). Rapid development is recently observed in the regions of USA, Europe, the Middle East, East and South East Asia (Timetric, 2013; Dittmer, 2001). This industry emerged through the advancement of private enterprise, flexibility and conditional relations to geographic regions, which expanded the requirement for travel accommodations (Sandoval-Strausz, 2007). Despite growth and healthy prospect, it is facing immense human resource challenges in the form of Organizational Justice (OJ) due to increased competition in the market (Laforet, 2013). Organizational justice is dealing employees with fairness and the construct is lately in focus of researchers on the subject of human resource management (Greenberg, 1990).

Organization justice is the most important component associated with any organization (Greenberg, 1990). From organizational behavior and HRM field, organizational justice gained the highest importance in past two decades (Jackson et al., 2014). It is essential for organizations 
Global Journal of Human Resource Management

Vol.8, No.1, pp.20-45, February 2020

Published by ECRTD-UK

Print ISSN: 2053-5686(Print), Online ISSN: 2053-5694(Online)

to hire competent employees to achieve a competitive advantage in the market (Jackson et al., 2014. Employees will react as they will be treated (Niehoff, B., \& Moorman, R., 1993). In innovative work behavior, fairness of perception is the most important factor that's why positive behavior depends on fairness of perception in organization (Kanter, 1988). Employees with high perception of justice will act positively because healthy social interaction depends upon a rair perception of justice. In other case, failing to instill trustworthiness and justice, the management will be facing so many problems with respect to employee's behavior and their performance (Cohen, R. L., \& Greenberg, J., 1982). In fact, the fundamental purpose of applying innovated behaviors in human resource management practices is to provide competitive advantages (Jackson et al., 2014).

In wake of global competition, rapid technical changes, and changing customer demands are calling upon more efficient and effective operations in hospitality industry in order to meet these challenges (Korczynski, 2002). In this scenario, the profitability of organizations depends upon meeting customer demands efficiently (Kaul \& Luo, 2016). The fundamental values of organizational justice have important consequences for working organizations. This is basically related to HRM practices and practitioners because awareness of equality is important for every individual in an organization (Ambrose, 2002). As the organizational justice reflects the fairness and consistency of actions (Jones \& Skarlicki, 2013) so, it will enhance the understanding of efficient human resource practices with innovative work behavior.

Researches in Organizational context extend their emphasis that injustice in work place leads negative and unfortunate responses (Cohen-Charash \& Spector, 2001; Colquitt, 2001; Conlon, D. E., \& Ross, W. H, (1997). Encountering injustice may result as decreased work performance (Pfeffer \& Langton, 1993). Along that injustice in work place will result into negative outcome and negative behavior (Hulin, 1991) increase job burnouts [] and decrease employee performance. Organizational injustice has gotten so much attention in recent research as its effect on the mental and physical health of employees, Specifically, researchers demonstrated that absence of organizational justice is linked to pressure and negative behavior of employees at work (Elovainio, Kivimaki, \& Helkama, 2001; Tepper, 2001; Fox, Spector, \& Miles, 2001).

Injustice provokes intense emotion in most people, and the more pertinent that injustice is to our own particular lives and experience, the more we faced difficulties and negativities, we start reacting and thinking in the same manners and perceive that every single thing is going in the wrong way (George JM, Br, 1992). Thoughts, about authoritative equity are infectious, conveyed from one individual to each other and kept up crosswise over gatherings (Degoey 2000). In doing as such, they recognize treachery as a rising issue (Kelloway, Francis, and Montgomery, 2005). Furthermore, the violation of organizational justice ethics has gotten impressive research consideration, mostly outcomes given by different researchers are related to behaviors for instance, organizational commitment (Alexander, Sinclair, \& Tetrick, 1995), burglary (Greenberg, 1990), and trust in the organization (Konovsky \& Pugh, 1994). Despite having a breadth of knowledge related to human behaviors that impact employee performance, there is need to explore deeper into the matter and seek industry specific behaviors that can provide insights to hit the sweet spot and get maximum from available human resource in hospitality industry. This study argues that 
Global Journal of Human Resource Management

Vol.8, No.1, pp.20-45, February 2020

Published by $E C R T D-U K$

Print ISSN: 2053-5686(Print), Online ISSN: 2053-5694(Online)

organizational justice is most important in the hotels because guests need special care, special service and positive behaviors of manager, have a key part in strengthening morale and improving relationship with them. This study basically investigates the impact of organizational justice on innovative work behavior of employees and how Human Resource Management Practices (Planning, Development, Appraisal, Compensation \& Rewards, Safety \& health, Labor relations and Human resource research) impact this relationship.

\section{This study is looking for answers to following questions:}

To what extent organizational justice (Distributive, procedural, informational, interactional) can impact the innovative work behavior of employees?

How HRMPs moderate the relationship between organizational justice and innovative work behavior of employees?

How HRMPs mediate the relationship between organizational justice and innovative work behavior of employees?

\section{LITERATURE REVIEW}

\section{Organizational Justice}

The concept of organizational justice was devolved by Greenberg in 1987 that was basically defining an employee's perception of fairness in working environment. The perception can be fair or unfair (Greenberg, 1987). Organizational justice is evaluation of employees about moral and ethical considerations of management (Cropanzano, Bowen \& Gilliland, 2007). Colquitt \& Greenberg (2003) categorized organizational justice in three forms which are distributive justice (DJ), procedural justice (PJ), and interactional justice (IJ) which is further divided into two forms which are informational justice (INFJ) and interpersonal justice (IPJ). Yigito \& Balaban.O (2018) considered distributive justice as distribution of gains, procedural justice as procedure of transactions and informational and internal-personal as interpersonal interaction. Distributive justice was extracted from equity theory that defines how certain individuals compare their consequences (rewards, working conditions etc.) to inputs (effort, skills, knowledge etc.) with those of other individuals (Adams, 1965).

Thibaut \& Walker (1975) contended that influence of employees towards outcomes was a vital factor of procedural justice, and Leventhal (1980) contended that procedures should be representative of employees' views and opinions and process should be perceived accurate, consistent, valuable and ethical. Interactional justice is humanistic and social in nature because it describes the perceptions that employees are well informed about their work in effective and efficient manners (Bies \& Moag, 1986). Further, it is studied as informational justice which explains whether there are good and enough justification when things go bad and against (Cropanzano, Bowen, \& Gilliland, 2007). Next is interpersonal justice that states the dignity of person like person acting respectfully with each other (Bies \& Moag, 1986).

Consequences of organizational justice in hotel industry;

- Highest level of relationship between interpersonal justice and organizational identification. (Gulluce C.A, \& Kahyaoglu. M., 2016). 
Global Journal of Human Resource Management

Vol.8, No.1, pp.20-45, February 2020

Published by $E C R T D-U K$

Print ISSN: 2053-5686(Print), Online ISSN: 2053-5694(Online)

- High level of organizational justice among the activities of their managers (Pelit \& Bozdoğan, 2014).

- A positive impact of organizational justice on employees' support for outsourcing in the hotel (Pablo Z, Jyh-Ming T, 2017).

- Strong positive effects of distributive justice on employees' job satisfaction working in casino (McCain C. S, Henry Tsai H, Bellino N, 2010).

\section{Innovative Work Behavior}

Janssen (2000) conceptualize Innovative work behavior (IWB) is purely related to human behavior so in this perspective Innovative Work Behavior (IWB) is, how people could encourage the accomplishment of start and deliberate presentation of new and helpful thoughts, procedures, items or methods (Farr and Ford, 1990). Scott and Bruce (1994) states innovative work behavior (IWB) is understood as an adequate multi-arrange process including idea generation, coalition building and implementation.

Yuan \& Woodman, (2010) described Innovative work behavior (IWB) of employees as the development, adoption and implementation of new ideas for products and work related procedures. De Jong and Hartog (2010) pointed out four interrelated arrangements of behavioral aspects idea recognition, idea generation, idea promotion, idea realization; these could enhance the capacity of workers.

- The initial two activities including idea recognition and idea generation stage, speaks to the creativity orientated work behavior phase (Leonga, and Raslib, 2013).

- The last 2 phases are denoted as implementation-oriented work behavior wherein people attempt to elevate an original plan to potential partners, administrators and to acknowledge genuine thoughts that are eventually connected inside the work role, group or aggregate association (Leonga, and Raslib, 2013).

Mumford (2000) stated that it's the individual who creates idea basically he/she is the best source of idea generation. Janseen (2000) depicted the concept of idea championing or idea promoting; he says once an idea is created it must be promoted for the improvement of product, process and services. Kleysen \& Street, (2001) conceptualize the final stage of Innovative Work Behavior according to him idea must be actualized and incorporated in real world. Bandura, (1986) supported the social cognitive theory in terms of behavior, which is a theory of learning, according to this perspective people learn by observing what others do and don't do, which means people learns by others' experiences. Kanter (1988) demonstrated individual innovative behavior into three forms which are: Approval of questions, determine answers and ideas, and generate a treaty for supporting these ideas.

\section{Organizational Justice and Innovative Work Behavior}

Organizational justice and behaviors of employers are acquiring much attention now- a- days (Janssen, 2000). Paradigm of behavior is shifting towards innovative behavior; generally innovation and specifically innovative work behavior are the core aspect in hospitality industry (De Spiegelaere, S., et al., 2014). Hsu and Wang (2015) concluded a strong relationship between organizational justice (distributive, procedural \& interactional justice) and innovative work 
Global Journal of Human Resource Management

Vol.8, No.1, pp.20-45, February 2020

Published by $E C R T D-U K$

Print ISSN: 2053-5686(Print), Online ISSN: 2053-5694(Online)

behaviors of employees.

Upasna A. Agarwal (2014) constructed following three different Models;

- Model 1 (mediating model) in which, paths of justice perceptions and psychological contract on trust was significantly impacted by work engagement

- Model 2 (partially mediating model) in which paths of justice perceptions and psychological contract to trust along with work engagement. Work engagement was impacted by both justice perception and psychological contract along with trust. Trust significantly impacted work engagement and work engagement was antecedent of innovative work behavior.

- Model 3 (non-mediating model), that observed the direct association between justice perception and psychological contract to work engagement. This model has also included path from work engagement to innovative work behavior but no mediation was seen between these variable.

Few studies showed the association between organizational justice and innovative work behavior from an empirical perspective so certain consequences are:

- Unfair treatment negatively impact the performance and behavior towards their contribution in work (Momeni, Ebrahimpour \& Ajirloo, 2014)

- interactional justice has direct and positive association with employee innovative work behavior (Almansour and Minai, 2012)

- positive relation of organizational justice and innovative work behavior (Kim and Lee, 2013)

- Temporal and spatial justice are most important for chinees employees (Akram, T.; Haider, M.J.; Feng, Y.X, 2016)

- Influence is low between organizational justice and innovative work behavior (Chao, $\mathrm{C}$. Y., Lin, Y. S., 2011)

- Absence of organizational justice can leads to negative behaviors (Skarlicki and Folger, 1997)

In literature, combined effects of innovative work behavior and (idea generation and idea implementation) were examined. In this study all sub-construct of Innovative work behavior (Idea generation, idea promotion, and idea realization) will be tested. So predicted hypothesis for organizational justice and innovative work behavior for this study are:

H1: Organizational justice has positive impact on innovative work behavior

$\mathrm{H}$ 2: Distributive justice has positive impact on innovative work behavior

$\mathrm{H} 2 \mathrm{a}$ : Distributive justice has positive impact on idea generation

$\mathrm{H} 2 \mathrm{~b}$ : Distributive justice has positive impact on idea promotion

$\mathrm{H} 2 \mathrm{c}$ : Distribution justice has positive impact on idea realization

Hypothesis 3: Procedural justice has positive impact on innovative work behavior

H3a: Procedural justice has positive impact on idea generation

H3b: Procedural justice has positive impact on idea promotion

$\mathrm{H} 3 \mathrm{c}$ : Procedural justice has positive impact on idea realization

Hypothesis 4: Information justice has positive impact on innovative work behavior

$\mathrm{H} 4 \mathrm{a}$ : Informational justice has positive impact on idea generation

$\mathrm{H} 4 \mathrm{~b}$ : Informational justice has positive impact on idea promotion 
Global Journal of Human Resource Management

Vol.8, No.1, pp.20-45, February 2020

Published by $E C R T D-U K$

Print ISSN: 2053-5686(Print), Online ISSN: 2053-5694(Online)

H4c: Informational justice has positive impact on idea realization

Hypothesis 5: Interpersonal justice has positive impact on innovative work behavior

H5a: Interpersonal justice has positive impact on idea generation

$\mathrm{H} 5 \mathrm{~b}$ : Interpersonal justice has positive impact on idea promotion

$\mathrm{H} 5 \mathrm{c}$ : Interpersonal justice has positive impact on idea realization

\section{Human Resource Management Practices}

Human Resource Management (HRM) rose in the mid-1980s and keeps on advancing as a different field of study (Hendry \& Pettigrew, 1990). Bratton and Gold (2003) characterized Human Resource Management (HRM) as planned approach to organize employment relationship that focuses on skills and capabilities of employees for maintaining competitive advantage.

Choi, J. N., (2010) defined for Human Resource Management (HRM), contribution of individual and organizations matter a lot in which they work as creativity of the organization depends on their personnel. Hosain, M. S. (2015) stated that Human Resource Management (HRM), is involved in not just in securing and improving the aptitudes of individual's workers but also working on different plans and programs to enhance cooperation and communication between individuals for organizational improvement and retaining employees in organization. Employees are the most important assets of any organizations that's why they must be treated well so; they can take part actively in all activities of hotels.

Mondy and Noe (1993) reported that activities and practices of HRM can be categorized in six different spheres:

- $\quad$ Planning and recruitment (P\&R)

- Development and appraisal (D\&A)

- Compensation and reward (C\&R)

- $\quad$ Safety and health $(\mathrm{S} \& H)$

- Labor relations (LR)

- Human resource research (HRR)

Wright and Snell, (1991) defined that Human Resource Management Practices (HRMPs), are as an organizational activities coordinated and dealing with the pool of HR, and guaranteeing that these assets are utilized towards the satisfaction of organizational goals. Taseem and Soeters (2006) have learned around eight HRM practices and Policies and their association with work fulfillment in business organization. Every country and every organization is different so, Human Resource Management Practices (HRMPs) may vary from one organization to another and from one country as well (Beugelsdijk, 2008; Codrina, 2008). Acquaah (2004) demonstrated that Human Resource Management practices improve performance and organizational effectiveness by appealing, recongnizing, and maintaining employees with knowledge, skill and positive behavior. Positive behavior is necessary for the implementation of Human Resource Management Practices.

In hunting down ways Human Resource (HR), and their administration, has turned out to be more crucial in the recent years

- $\quad$ Talented workforce is required for organizational growth (Chawdhury, 2002) 
Global Journal of Human Resource Management

Vol.8, No.1, pp.20-45, February 2020

Published by ECRTD-UK

Print ISSN: 2053-5686(Print), Online ISSN: 2053-5694(Online)

- Human Resource Management practice (Planning, selection, promotion, training, feedback) have significant relationship with efficiency and effectiveness (Pareek \& Rao, 2007)

\section{Human Resource Management Practices and Innovative work behavior}

Business organizations can stimulate required behaviors by utilizing HRM practices that support particular states of mind and behaviors, and discourage undesired behavior and practices (Alfes, K., Shantz, A., Truss, C. and Soan, E., 2013). Jimenez and Valle (2008) mentioned in their survey on 173 Spanish organizations that Human Resource Management Practices (HRMPs) (career opportunity, performance Appraisal, compensation and benefits) effectively improve the organizational innovation. Chang et al., 2011) examined the role of incremental and radical innovation through HRM practices (selection and training). They concluded that both practices have positive effect on incremental and radical innovation in hospitality industry. Prieto and Perez-Santana (2014) investigated the role of human resource management practices and innovative work behavior. This study showed no direct association was seen motivation-enhancing HR practices and innovative work behavior. Jiang, Wang and Zhao (2012) observed that recruitment and selection, reward, job design and teamwork were significantly related to innovative behavior of employees. In this study creativity of employees mediated between hiring $\&$ selection, reward, job design \& teamwork and innovative behavior.

Numerous researchers have discovered to help for a linkage between HRMPs and innovation. Some consequence of Human Resource Management Practices and innovative Work Behavior are; - $\quad$ Extensive training effects innovative work behavior (Fernandez \& Pitts, 2011)

- Significant association between competence development and innovative work behavior (IWB) (Bysted \& Jespersen, 2012)

- $\quad$ HRM practices (performance appraisal, career management, training, reward system and recruitment) have a significant positive impact on innovative behavior Further the knowledge Management mediated between HRMPs and IWB (Tan and Nasurdin (2011).

- Multifunctional job design has a significant relationship with innovative work behavior (Dorenbosch, L., Van Engen, M. L., \& Verhagen, M., 2005)

However, employees' innovative behaviors and practices are fundamental to the creative limit of organization as people can be observed as the foundation of each (Foss, N. J., Laursen, K., and Pedersen, T., 2011). So, predicted hypothesis for moderating effect of HRMPs between organizational justice and innovative work behavior are:

H6: HRMPs moderate the relationship between organizational justice and innovative work behavior

H6a: Recruitment and selection moderate the relationship between organizational justice and innovative Work behavior.

H6b: Training and development moderate the relationship between organizational justice and innovative work behavior.

H6c: Compensation and benefit moderate the relationship between organizational justice and innovative work behavior.

H6d: Performance appraisal moderates the relationship between organizational justice and innovative work behavior. 
Global Journal of Human Resource Management

Vol.8, No.1, pp.20-45, February 2020

Published by $E C R T D-U K$

Print ISSN: 2053-5686(Print), Online ISSN: 2053-5694(Online)

H6e: Participation moderates the relationship between organizational justice and innovative work behavior.

Similarly predicted hypothesis for mediating effect of HRMPs between organizational justice and innovative work behavior are:

H7: HR Practices mediate the relationship between organizational justice and innovative work behavior

H7a: Recruitment and selection mediate the relationship between organizational justice and innovative Work behavior

H7b: Training and development mediate the relationship between organizational justice and innovative work behavior.

H7c: Compensation and benefit mediate the relationship between organizational justice and innovative work behavior

H7d: Performance appraisal mediates the relationship between organizational justice and innovative work behavior

H7e: Participation mediates the relationship between organizational justice and innovative work behavior.

\section{METHOD}

This research was conducted on different hotels located in Karachi, Pakistan, with the aim to investigate the moderating/mediating effects of HRMPs in organizational justice on innovative work behavior. A quantitative approach was adopted for conducting this survey. Sample of 52 individuals is selected for this study. Top and Middle management is targeted as they have knowledge, experience and better understanding regarding various aspects of Organizational justice, HRMPs and innovative work behavior. For data collection 5 hotels of Karachi are selected. Data was collected by distributing questionnaires personally visiting all hotels one by one and collected by hand.

The response rate of individuals was covered in Table 1.

\section{Measurement scales}

A structured questionnaire was utilized to make sure that there was standardization in the response given and in gathering of data. So, data was collected from respondents through questionnaire. Questionnaires against all variables are adopted and measured using five point Likert's scale starting from strongly disagrees to strongly agree/very little extent to very great extent.For measuring organizational justice scale of (Colquitt's, 2001) and (Niehoff and Moorman, 1993) is adopted. The items for Distributive justice (DJ) and Procedural justice (PJ) are adapted from (Niehoff and Moorman, 1993). The questionnaire to measure Distributive justice and Procedural justice included items such as "I consider my workload to be quite fair." and "My hotel has procedures that are designed to allow the requests for clear explanation or additional information about a decision". The items for Interpersonal justice and Informational justice are adapted from (Colquitts, 2000). The questionnaire to measure Interpersonal justice (IJ) and Informational justice (INFJ) included items such as "I am being treated with dignity in my hotel." and "Procedures are explained thoroughly in my hotel". 
Global Journal of Human Resource Management

Vol.8, No.1, pp.20-45, February 2020

Published by $E C R T D-U K$

Print ISSN: 2053-5686(Print), Online ISSN: 2053-5694(Online)

For Innovative work behavior scale of (janseen, 2000) is adopted that represented nine items and measured the extent of individual idea generation, promotion, and implementation. The questionnaire to measure Idea Generation (IG), Idea Promotion (IP), and Idea Realization (IR) included items such as "I am generating original solutions for problems", "I am acquiring approval for innovative ideas "and "I am evaluating the utility of innovative ideas"

For HRMPs scale of (Chen and Huang (2009) and Masood (2010) is adopted. For measuring Recruitment \& selection, all four questions are selected. The questionnaire, to measure Recruitment \& Selection, included items such as "our hotel has clear criteria for employee selection". For measuring Training, five questions are selected out of seven. The questionnaire to measure Training, included items such as "Training is available for new hires in my hotel". For measuring Compensation and benefits, three questions are selected out of eight. The questionnaire, to measure Compensation, included items such as "The compensation for all employees is directly linked to their performance".

For measuring performance appraisal, four questions are selected out of ten. The questionnaire to measure performance appraisal, included items such as "Appraisal system is unbiased and transparent". For measuring participation, items from HRMPs five questions are selected out of ten. The questionnaire to measure Participation, included items such as "Employees are asked by superiors to participate in related decisions."

\section{RESULTS}

Data was gathered through questionnaires, after that it was transformed into coded form for analysis purpose. Hence, Statistical Package for Social Sciences (SPSS) version 25 was used for data analysis. To ensure the reliability of the instruments Cronbach 'Alpha was applied. The Value of Cronbach 'Alpha is used to authenticate the reliability of the constructs (H.G. Osburn, 2000). The overall reliability of the proposed model is .880 that indicates the model is extremely reliable to use.

\section{Demographic Variables}

For this study 8 items are included to measure demographic variables, including gender, age, education, , current position, household income, current status, tenure, and staff supervision. Descriptive statistics for demographic variables related to gender respondent depicts that $78 \%$ of employees' are men and, 22\% of employees' are females. Education shows that $82 \%$ of employees have master degrees which indicate that employees have capability to compete with competitors and have flexibility to understand every kind of circumstances. 
Global Journal of Human Resource Management

Vol.8, No.1, pp.20-45, February 2020

Published by ECRTD-UK

Print ISSN: 2053-5686(Print), Online ISSN: 2053-5694(Online)

\section{Correlation Analysis}

Pearson Correlation Analysis is used in this study to observe the association between dependent and independents variables. According to statistical results the value of Pearson correlation between organization justice and innovative work behavior is (.344) which is showing positive association between organizational justice and innovative work behavior. Distributive justice has value (0.037) which is showing positive but weak association with innovative work behavior. Procedural justice has value $(0.414)$ which is showing positive and moderate association with innovative work behavior. Interpersonal justice has value $(-0.141)$ which is showing negative and weak association with innovative work behavior. Informational justice has value $(0.472)$ which is showing positive and moderate association with innovative work behavior. So outcomes show overall association between dependent and independent variables are moderate except interpersonal justice.

Table: 1

\begin{tabular}{lllllll}
$\begin{array}{l}\text { Response } \\
\text { rate }\end{array}$ & $\begin{array}{l}\text { Selected } \\
\text { Industr } \\
\mathbf{y}\end{array}$ & $\begin{array}{l}\text { Distributed } \\
\text { Questionna } \\
\text { ires }\end{array}$ & $\begin{array}{l}\text { Received } \\
\text { Questionna } \\
\text { ires }\end{array}$ & $\begin{array}{l}\text { Not } \\
\text { received } \\
\text { Questionna } \\
\text { ires }\end{array}$ & $\begin{array}{l}\text { Rejected } \\
\text { Questionna } \\
\text { ires }\end{array}$ & $\begin{array}{l}\text { Response } \\
\text { rate }\end{array}$ \\
& & & & & & \\
& $\begin{array}{l}\text { Hotels } \\
\text { of }\end{array}$ & 52 & 50 & 2 & 0 & $96 \%$ \\
Karachi & & & & & \\
\hline
\end{tabular}


Global Journal of Human Resource Management

Vol.8, No.1, pp.20-45, February 2020

Published by $E C R T D-U K$

Print ISSN: 2053-5686(Print), Online ISSN: 2053-5694(Online)

Figure: 1

Proposed Conceptual Framework

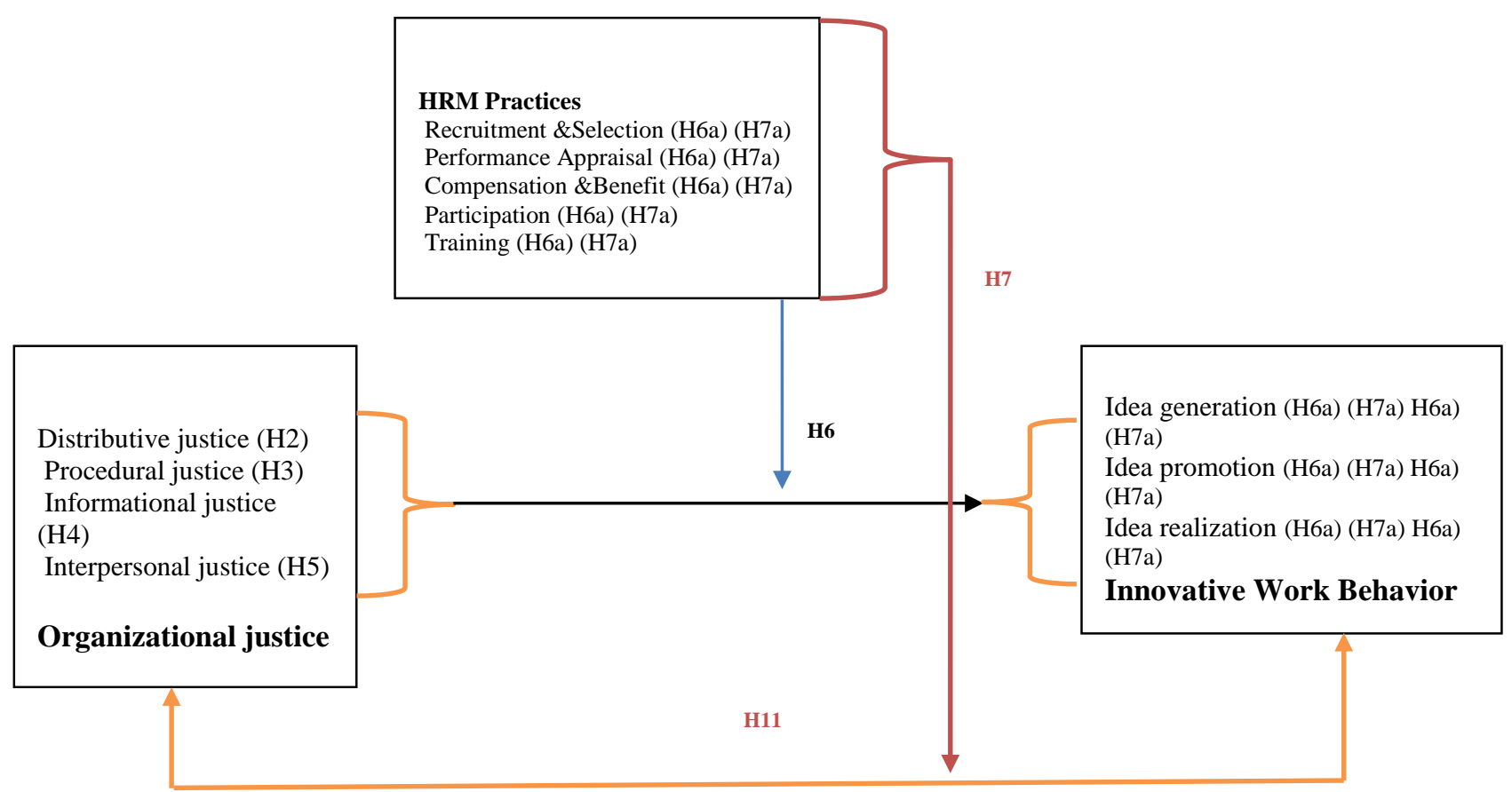


Global Journal of Human Resource Management

Vol.8, No.1, pp.20-45, February 2020

Published by ECRTD-UK

Print ISSN: 2053-5686(Print), Online ISSN: 2053-5694(Online)

Table2:

Demographics and other characteristics, e.g., gender, age, education, current profession, income, working hours, staff supervision

\begin{tabular}{|c|c|c|c|}
\hline characteristics & Female $n=11$ & Male $n=39$ & Total $n=50$ \\
\hline \multicolumn{4}{|l|}{ Age } \\
\hline$<25$ & $1(9.09 \%)$ & 0 & $1(2 \%)$ \\
\hline $25-30$ & 0 & 0 & 0 \\
\hline $31-35$ & $5(45.45 \%)$ & $9(23.07 \%)$ & $14(28 \%)$ \\
\hline $36-40$ & $4(36.36 \%)$ & $15(38.46 \%)$ & $19(38 \%)$ \\
\hline $41-45$ & $1(9.09 \%)$ & $11(28.20 \%)$ & $12(24 \%)$ \\
\hline$>45$ & 0 & $4(10.25 \%)$ & $4(8 \%)$ \\
\hline \multicolumn{4}{|l|}{ Education } \\
\hline Inter & 0 & 0 & 0 \\
\hline Bachelor & $3(27.27 \%)$ & $5(12.82 \%)$ & $8(16 \%)$ \\
\hline Master & $8(72.72 \%)$ & $33(84.61 \%)$ & $41(82 \%)$ \\
\hline MPhil & 0 & $1(2.56 \%)$ & $1(2 \%)$ \\
\hline Other & 0 & 0 & 0 \\
\hline \multicolumn{4}{|l|}{ Current Profession } \\
\hline Director & 0 & $9(23.07 \%)$ & $9(18 \%)$ \\
\hline Manager & $6(54.54 \%)$ & $17(43.58 \%)$ & $24(48 \%)$ \\
\hline Administrative Assistant & $2(18.18 \%)$ & $6(15.38 \%)$ & $8(16 \%)$ \\
\hline Advisor & $1(9.09 \%)$ & $2(5.12 \%)$ & $3(6 \%)$ \\
\hline $\begin{array}{l}\text { Middle Management } \\
\text { Income }\end{array}$ & $2(18.18 \%)$ & $5(12.82 \%)$ & $7(14 \%)$ \\
\hline$<20000$ & $1(9.09 \%)$ & 0 & $1(\%)$ \\
\hline 20001-300000 & 0 & 0 & 0 \\
\hline $30001-40000$ & $1(9.09 \%)$ & $3(7.69 \%)$ & $4(8 \%)$ \\
\hline $40001-50000$ & $2(18.18 \%)$ & $6(15.38 \%)$ & $8(16 \%)$ \\
\hline$>50000$ & $7(63.63 \%)$ & $30(76.92 \%)$ & $37(74 \%)$ \\
\hline \multicolumn{4}{|l|}{ Working Year(s) } \\
\hline $0-2 y r s$ & $4(36.36 \%)$ & $6(15.38 \%)$ & $10(20 \%)$ \\
\hline $3-5$ yrs. & $1(9.09 \%)$ & $11(28.20 \%)$ & $12(24 \%)$ \\
\hline $6-8 y r s$ & $5(45.45 \%)$ & $14(35.89 \%)$ & $19(38 \%)$ \\
\hline $9-10 y r s$ & 0 & $6(15.38 \%)$ & $6(12 \%)$ \\
\hline$>10$ yrs. & $1(9.09 \%)$ & $2(5.12 \%)$ & $3(6 \%)$ \\
\hline \multicolumn{4}{|l|}{ Staff Supervision } \\
\hline 1-3employees & $2(18.18 \%)$ & $4(10.25 \%)$ & $6(12 \%)$ \\
\hline 4-7 employees & 0 & $11(28.20 \%)$ & $11(22 \%)$ \\
\hline 8-10 employees & $2(18.18 \%)$ & $7(17.94 \%)$ & $9(18 \%)$ \\
\hline >10 employees & $5(45.45 \%)$ & $14(35.89 \%)$ & $19(38 \%)$ \\
\hline None & $2(18.18 \%)$ & $3(7.69 \%)$ & $5(10 \%)$ \\
\hline
\end{tabular}


Global Journal of Human Resource Management Vol.8, No.1, pp.20-45, February 2020

Published by ECRTD-UK

\section{Table.3}

Correlation

\section{Correlation}

\# Variables

Mean SD 1

Print ISSN: 2053-5686(Print), Online ISSN: 2053-5694(Online)

1 Organizational justice

$\begin{array}{lll}3.8947 & 0.3127 & 1(.579)\end{array}$

Distributive Justice

$\begin{array}{llll}3.8584 & 0.4160 \quad .452^{* *} \quad(.689\end{array}$

3 Procedural Justice

$\begin{array}{lllll}3.9751 & 0.4423 & .689^{* *} & 0.210 & (.606)\end{array}$

$4 \quad$ Interpersonal Justice

$3.6558 \quad 0.5660 .413^{* *}-$

$\begin{array}{lll}- & -0.075 \quad(.748)\end{array}$

5 Informational justice

4.0895

$0.153 .566^{* *}$

$0.026 \quad(.596)$

Innovative

work

4.1634

3

6 Behaviors

0.254

$$
7
$$

4.2429

0.3736

$.344^{*}$

$0.037 .414^{* *}$

$-0.141 .472^{* *}$

(.624)

7 Idea Generalization

$$
6
$$

$-0.105$

$-0.093$

$-0.070$

$\begin{array}{lll}-0.173 & 0.055 & .504^{* *}\end{array}$

$(.713)$

8 Idea Promotion

$4.1225 \quad 0.4173 \quad .476^{* *}$

$0.161 .386^{* *}$

0.112

$.446^{* *}$

$.575^{* *}$

$-0.106 \quad(.628$

3

9 Idea Realization

$\begin{array}{lll}4.1246 & 0.4569 & 0.225 \\ 7 & \end{array}$

$-$

$-0.196 .335^{*} \quad .731^{* *}$

0.120

0.132

$1(.65$

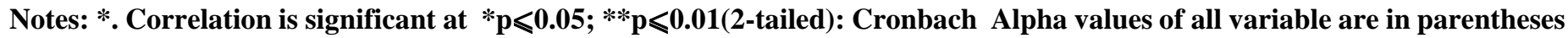


Global Journal of Human Resource Management Vol.8, No.1, pp.20-45, February 2020

Published by ECRTD-UK

Print ISSN: 2053-5686(Print), Online ISSN: 2053-5694(Online)

Table:

Regression

Analysis

\begin{tabular}{|c|c|c|c|c|c|c|c|}
\hline Mode & Variables & & $\mathbf{R 2}$ & F-Value & Beta-Value & Sig & Hypothesis \\
\hline & IV & DV & & & & & \\
\hline $\mathrm{H} 1$ & Org_J & IWB & .118 & 6.453 & .280 & .014 & Accepted \\
\hline $\mathrm{H} 2$ & DIS_J & IWB & .001 & .065 & .022 & .800 & Rejected \\
\hline $\mathrm{H} 2 \mathrm{a}$ & DIS_J & $\begin{array}{l}\text { IG_IW } \\
\text { B }\end{array}$ & .009 & .417 & -.083 & .521 & Rejected \\
\hline $\mathrm{H} 2 \mathrm{~b}$ & DIS_J & $\begin{array}{l}\text { IP_IW } \\
\text { B }\end{array}$ & .026 & 1.278 & .162 & .264 & Rejected \\
\hline $\mathrm{H} 2 \mathrm{c}$ & DIS_J & $\begin{array}{l}\text { IR_IW } \\
\text { B }\end{array}$ & .000 & .005 & -.011 & .946 & Rejected \\
\hline $\mathrm{H} 3$ & PRO_J & IWB & .171 & 9.914 & .238 & .003 & Accepted \\
\hline $\mathrm{H} 3 \mathrm{a}$ & PRO_J & $\begin{array}{l}\text { IG_IW } \\
\text { B }\end{array}$ & .005 & .237 & -.059 & .628 & Rejected \\
\hline $\mathrm{H} 3 \mathrm{~b}$ & PRO_J & $\begin{array}{l}\text { IP_IW } \\
\text { B }\end{array}$ & .149 & 8.401 & .364 & .006 & Accepted \\
\hline $\mathrm{H} 3 \mathrm{c}$ & PRO_J & $\begin{array}{l}\text { IR_IW } \\
\text { B }\end{array}$ & .156 & 8.874 & .408 & .005 & Accepted \\
\hline $\mathrm{H} 4$ & I_J & IWB & .020 & .975 & -.063 & .328 & Rejected \\
\hline $\mathrm{H} 4 \mathrm{a}$ & I_J & $\begin{array}{l}\text { IG_IW } \\
\text { B }\end{array}$ & .030 & 1.481 & -.114 & .230 & Rejected \\
\hline $\mathrm{H} 4 \mathrm{~b}$ & I_J & $\begin{array}{l}\text { IP_IW } \\
\text { B }\end{array}$ & .012 & .605 & .082 & .441 & Rejected \\
\hline $\mathrm{H} 4 \mathrm{c}$ & I_J & $\begin{array}{l}\text { IR_IW } \\
\text { B }\end{array}$ & .038 & 1.913 & -.158 & .173 & Rejected \\
\hline H5 & INF_J & IWB & .233 & 13.738 & .181 & .001 & Accepted \\
\hline $\mathrm{H} 5 \mathrm{a}$ & INF_J & $\begin{array}{l}\text { IG_IW } \\
\text { B }\end{array}$ & .003 & .144 & .031 & .706 & Rejected \\
\hline $\mathrm{H} 5 \mathrm{~b}$ & INF_J & $\begin{array}{l}\text { IP_IW } \\
\text { B }\end{array}$ & .199 & 11.906 & .281 & .001 & Accepted \\
\hline $\mathrm{H} 5 \mathrm{c}$ & INF_J & $\begin{array}{l}\text { IR_IW } \\
\text { B }\end{array}$ & .112 & 6.068 & .231 & .017 & Accepted \\
\hline
\end{tabular}


Global Journal of Human Resource Management

Vol.8, No.1, pp.20-45, February 2020

Published by ECRTD-UK

Print ISSN: 2053-5686(Print), Online ISSN: 2053-5694(Online)

Table: 5 Moderation Analysis
Table: 6 Mediation Analysis

\begin{tabular}{llllll}
\hline Hypothesis & M.V & R & $\begin{array}{l}\text { F- } \\
\text { change }\end{array}$ & Sig & Hypothesis \\
H6 & ORGJ_HRMP & .551 & 1.134 & .293 & Rejected \\
H6a & ORGJ_SHRMP & .403 & .358 & .553 & Rejected \\
H6b & ORGJ_THRMP & .561 & 10.678 & .002 & Accepted \\
H6c & ORGJ_CHRMP & .594 & 15.115 & .000 & Accepted \\
H6d & ORGJ_PAHRMP & .568 & 7.465 & .009 & Accepted \\
H6e & ORGJ_PHRMP & .526 & 8.569 & .005 & Accepted \\
\hline
\end{tabular}

\begin{tabular}{lllll}
\hline Hypothesis & Mediator & Sobel Test & P-value & Hypothesis \\
H7 & HRM_P & 2.11463876 & 0.03446075 & Accepted \\
H7a & S_HRMP & 1.31695183 & 0.18785492 & Rejected \\
H7b & T_HRMP & 1.17424623 & 0.24029641 & Rejected \\
H7c & C_HRMP & 1.53873871 & 0.1238681 & Rejected \\
H7d & PA_HRMP & -0.62792389 & 0.5300538 & Rejected \\
H7e & P_HRMP & 1.19643125 & 0.23152831 & Rejected \\
\hline
\end{tabular}

The regression analysis indicates the amount of one variable affects the other alongside its course of effect (Aiken, L. S., \& West, S.G. (1991). In the present examination, Organizational justice with its four constructs was independent variable though the innovative work behavior was outcome variable.

At first, the effect of organization justice on innovative work behavior was estimated (H1). Empirical evidence proves that there is positive/significant relationship of organizational justice towards innovative work behavior. The estimation of R2 (0.118) demonstrates that this model explains $11.8 \%$ effect of organizational justice on innovative work behavior and remaining is explained by others different variable. F-Value demonstrates that the model is significant. Beta coefficient value of organizational justice is .280 , which means that every unit increase in organizational justice will result in 0.280 units increase in innovative work behavior. As significant level of $\mathrm{P}<0.05 \Rightarrow 0.014<0.05$. So, researcher concluded at $95 \%$ confidence interval, is failed to reject the $\mathrm{H} 1$ (alternate) and failed to accept null hypothesis on the basis of findings.

Secondly, the effect of distributive justice on innovative work behavior was estimated (H2). Empirical evidence proves that there is insignificant relationship. The estimation of R2 (0.001) demonstrates that this model explains only $0.1 \%$ effect of distributive justice on innovative work behavior and remaining is explained by others different variable. F-Value demonstrates that the model is insignificant. Beta coefficient of distributive justice is 0.022 , which means that every unit increase in distributive justice will result in 0.022 unit increase in innovative work behavior. As 
Global Journal of Human Resource Management

Vol.8, No.1, pp.20-45, February 2020

Published by ECRTD-UK

Print ISSN: 2053-5686(Print), Online ISSN: 2053-5694(Online)

significant level of $\mathrm{P}>0.05=>0.800>0.05$. So, researcher concluded at $95 \%$ confidence interval, is failed to accept the $\mathrm{H} 2$ (alternate) and failed to reject null hypothesis on the basis of findings. The effect of distributive justice was estimated on sub-variables of innovative work behavior which are idea generation, idea promotion, and idea realization. As significant level of $\mathrm{P}<0.05=>$ $0.521>0.05$. So, researcher concluded at $95 \%$ confidence interval is failed to accept the H2a (alternate) and failed to reject null hypothesis on the basis of findings. Along this significant level of $\mathrm{P}<0.05=>0.264>0.05$ for $\mathbf{H 2 b}$. So, researcher concluded at $95 \%$ confidence interval is failed to accept the $\mathrm{H} 2 \mathrm{~b}$ (alternate) and failed to reject null hypothesis on the basis of findings. Similarly significant level of $\mathrm{P}<0.05=>0.946>0.05$ for H2c. So, researcher concluded at $95 \%$ confidence interval is failed to accept the $\mathrm{H} 2 \mathrm{c}$ (alternate) and failed to reject null hypothesis on the basis of findings.

Thirdly, the effect of procedural justice on innovative work behavior was estimated (H3). Empirical evidence proves that there is positive/significant relationship of procedural justice towards innovative work behavior. The estimation of R2 (0.171) demonstrates that this model explains $17.1 \%$ effect of organizational justice on innovative work behavior and remaining is explained by others different variable. F-Value demonstrates that the model is significant. Beta coefficient of procedural justice is .238 , which means that every unit increase in organizational justice will result in 0.23.8 unit increase in innovative work behavior. As significant level of $\mathrm{P}<$ $0.05=>0.003<0.05$. So, researcher concluded at $95 \%$ confidence interval is failed to reject the $\mathrm{H} 3$ (alternate) and failed to accept null hypothesis on the basis of findings. The effect of procedural justice was estimated on sub-variables of innovative work behavior which are idea generation, idea promotion, and idea realization. As significant level of $\mathrm{P}<0.05=>0.628>0.05$ for H3a. So, researcher concluded at 95\% confidence interval is failed to accept the H3a (alternate) and failed to reject null hypothesis on the basis of findings. And significant level of $\mathrm{P}<0.05=>0.006<0.05$ for $\mathbf{H 3 b}$. So, researcher concluded at $95 \%$ confidence interval is failed to reject the $\mathrm{H} 3 \mathrm{~b}$ (alternate) and failed to accept null hypothesis on the basis of findings. As significant level of $\mathrm{P}<0.05=>$ $0.005<0.05$ for $\mathrm{H} 3 \mathrm{c}$. So, researcher concluded at $95 \%$ confidence interval is failed to reject the H3c (alternate) and failed to accept null hypothesis on the basis of findings.

Fourthly, the effect of interpersonal justice on innovative work behavior was estimated (H4). Empirical evidence proves that there is a insignificant relationship of interpersonal justice towards innovative work behavior. The estimation of R2 (0.020) demonstrates that this model explains $2.0 \%$ effect of organizational justice on innovative work behavior and remaining is explained by others different variable. F-Value demonstrates that the model is significant. Beta coefficient of procedural justice is -0.059 , which means that every unit increase in organizational justice will result in -0.059 unit decrease in innovative work behavior. As significant level of $\mathrm{P}<0.05 \Rightarrow$ $0.328>0.05$. So, researcher concluded at $95 \%$ confidence interval is failed to accept the $\mathrm{H} 4$ (alternate) and failed to reject null hypothesis on the basis of findings. The effect of interpersonal justice was estimated on sub-variables of innovative work behavior which are idea generation, idea promotion, and idea realization. As significant level of $\mathrm{P}<0.05=>0.230>0.05$ for H4a. So, researcher concluded at $95 \%$ confidence interval is failed to accept the $\mathbf{H 4 a}$ (alternate) and failed to reject null hypothesis on the basis of findings. And significant level of $\mathrm{P}<0.05=>0.441>0.05$ for $\mathrm{H} 4 \mathrm{~b}$. So, researcher concluded at $95 \%$ confidence interval is failed to accept the $\mathbf{H 4 b}$ (alternate) 
Global Journal of Human Resource Management

Vol.8, No.1, pp.20-45, February 2020

Published by ECRTD-UK

Print ISSN: 2053-5686(Print), Online ISSN: 2053-5694(Online)

and failed to reject null hypothesis on the basis of findings. As significant level of $\mathrm{P}<0.05=>$ $0.173>0.05$ for H4c. So, researcher concluded at $95 \%$ confidence interval is failed to accept the $\mathbf{H 4 c}$ (alternate) and failed to reject the null hypothesis on the basis of findings.

Furthermore, the effect of informational justice on innovative work behavior was estimated (H5). Empirical evidence proves that there is significant relationship of informational justice towards innovative work behavior. The estimation of R2 (.233) demonstrates that this model explains $23.3 \%$ effect of organizational justice on innovative work behavior and remaining is explained by others different variable. F-Value demonstrates that the model is significant. Beta coefficient of informational justice is .181 , which means that every unit increase in organizational justice will result in 0.181 unit increase in innovative work behavior. As significant level of $\mathrm{P}<$ $0.05=>0.001<0.05$. So, researcher concluded at $95 \%$ confidence interval is failed to reject the H5 (alternate) and failed to accept null hypothesis on the basis of findings. The effect of procedural justice was estimated on sub-variables of innovative work behavior which are idea generation, idea promotion, and idea realization. As significant level of $\mathrm{P}<0.05=>0.706>0.05$. So, it is researcher concluded at 95\% confidence interval researcher is failed to accept the H5a (alternate) and failed to reject null hypothesis on the basis of findings. And significant level of $\mathrm{P}<0.05=>0.001<0.05$. So, it is concluded at $95 \%$ confidence interval researcher is failed to reject the $\mathbf{H 5 b}$ (alternate) and failed to accept null hypothesis on the basis of findings. As significant level of $\mathrm{P}<$ $0.05=>0.017<0.05$. So, it is concluded at $95 \%$ confidence interval researcher is failed to reject the H5c (alternate) and failed to accept null hypothesis on the basis of findings.

In moderating scenario human resource management practices are tested through multiple regressions or Prof. Andrew Hayes process method to examine the moderation between organizational justice and innovative work behavior. For this purpose first need to compute the numeric interactions after completing the interaction process, researcher comes out the value of ORGJ_HRMP (H6) is 0.293>0.05 which is not signicant, So, human resource management practice(s) is not playing moderating role between organizational justice and innovative work behavior. That's why it is concluded at $95 \%$ confidence interval researcher is failed to accept the H6 (alternate) and failed to reject null hypothesis on the basis of findings.

Findings shows the value of ORGJJ_SHRMP (H6a) is not signicant at 0.553 which is greater than 0.05. So, Recruitment and selection is not playing moderating role between organizational justice and innovative work behavior. That's why it is concluded at $95 \%$ confidence interval researcher is failed to accept the H6a (alternate) and failed to reject null hypothesis on the basis of findings. Findings show the value of ORGJ_THRMP (H6b) is signicant at 0.002, as it is less than 0.05. So, Training and development is playing moderating role between organizational justice and innovative work behavior. That's why it is concluded at $95 \%$ confidence interval researcher is failed to reject the H6c (alternate) and failed to accept null hypothesis on the basis of findings. Findings show the value of ORGJ_CHRMP (H6c) is signicant as P-Value is .000 which is less than 0.05. So, Compensation and benefits is playing moderating role between organizational justice and innovative work behavior. That's why it is concluded at $95 \%$ confidence interval researcher is failed to reject the H6c (alternate) and failed to accept null hypothesis on the basis of findings. Findings show the value of ORGJ_PAHRMP (H6d) is signicant as P-Value is less than 
Global Journal of Human Resource Management

Vol.8, No.1, pp.20-45, February 2020

Published by ECRTD-UK

Print ISSN: 2053-5686(Print), Online ISSN: 2053-5694(Online)

0.05. So, Recruitment and selection is playing moderating role between organizational justice and innovative work behavior. That's why it is concluded at $95 \%$ confidence interval researcher is failed to reject the H6d (alternate) and failed to accept null hypothesis on the basis of findings. Findings show the value of ORGJ_PHRMP (H6e) is signicant at 0.005 which is less than 0.05. So, Participation is playing moderating role between organizational justice and innovative work behavior. That's why it is concluded at $95 \%$ confidence interval researcher is failed to reject the H6e (alternate) and failed to accept null hypothesis on the basis of findings.

To test the mediation sobel test or Prof. Andrew Hayes (Model 4) is applied. Sobel and Hayes outcomes are same. So mediation of HRMPs between organizational justice and innovative work behavior (H7) is 2.114 that's sobel value and signicant at $0.034<.05$ which mean mediation is existing there. That's why it is concluded at $95 \%$ confidence interval researcher is failed to reject the $\mathrm{H} 7$ (alternate) and failed to accept null hypothesis on the basis of findings.

Mediation of Recruitment and selection (HRMPs) between organizational justice and innovative work behavior (H7a) is 1.3169 (sobel value) which is not signicant at .187>0.05 so mediation effect is not exiting here. That's why it is concluded at $95 \%$ confidence interval researcher is failed to accept the $\mathrm{H7a}$ (alternate) and failed to reject null hypothesis on the basis of findings.

Mediation of Training and Development (HRMPs) between organizational justice and innovative work behavior (H7b) is1.1742 (sobel value) which is not signicant at $0.240>0.05$ so mediation effect is not exiting here. That's why it is concluded at $95 \%$ confidence interval researcher is failed to accept the $\mathrm{H} 7 \mathrm{~b}$ (alternate) and failed to reject null hypothesis on the basis of findings.

Mediation of compensation and benefits (HRMPs) between organizational justice and innovative work behavior (H7c) is 1.538(sobel value) which is signicant not at 0.1238>.05 so mediation effect is not exiting here. That's why it is concluded at $95 \%$ confidence interval researcher is failed to accept the $\mathrm{H} 7 \mathrm{c}$ (alternate) and failed to reject null hypothesis on the basis of findings.

Mediation of performance Appraisal (HRMPs) between organizational justice and innovative work behavior (H7d) is -0.6279 (sobel value) which is not signicant at $0.5300>0.05$ so mediation effect is not exiting here. That's why it is concluded at $95 \%$ confidence interval researcher is failed to accept the $\mathrm{H} 7 \mathrm{~d}$ (alternate) and failed to reject null hypothesis on the basis of findings.

Mediation of Participation (HRMPs) between organizational justice and innovative work behavior (H7e) is 1.1964 (sobel value) which is not signicant at $0.2315<0.05$ so mediation effect is not exiting here. That's why it is concluded at $95 \%$ confidence interval researcher is failed to accept the H7e (alternate) and failed to reject null hypothesis on the basis of findings.

\section{DISCUSSION}

This study was an effort to find out the answers of these questions as under:

To what extent organizational justice (distributive, procedural, informational, interactional) can impact the innovative work behavior of employees?

How HRMPs moderate the relationship between organizational justice and innovative work 
Global Journal of Human Resource Management

Vol.8, No.1, pp.20-45, February 2020

Published by $E C R T D-U K$

Print ISSN: 2053-5686(Print), Online ISSN: 2053-5694(Online)

behavior of employees?

How HRMPs mediate the relationship between organizational justice and innovative work behavior of employees?

To answer these questions 7 main hypotheses were tested in different ways like correlation, regression; multiple regression and sobel test.

To what extent organizational justice (distributive, procedural, informational, interactional) can impact the innovative work behavior of employees?

For this question four hypotheses were tested, outcomes were significantly in favor of overall organizational justice hypothesis; consequently, this hypothesis was accepted. Previously, organizational justice was tested with employee' performance (Kalay F, 2016), citizenship behavior (Silva. H. M. S. V \& Madhumali. K. P. W. C., 2014) that's shows positive impact. In current study, distributive justice and interpersonal justice has no impact on employees' innovative work behavior. Procedural justice has positive and significant impact on employees' innovative behavior overall but when it was tested with all elements of innovative work behavior like idea generation, idea promotion and idea realization so it seems insignificant impact Idea generation rest two have significant impact. Informational justice has positive and significant impact on employees' innovative work behavior overall but when it was tested with all elements of innovative work behavior like idea generation, idea promotion and idea realization so except idea generation it was positive with all others dimensions.

In previous studies distributive justice with performance (Kalay F, 2016) and, procedural justice with performance (Zapata-Phelan, C. P., et al., 2008; Iqbal MZ, Rehan M, Fatima A, Nawab S, 2017) showed positive impact. Organizational justice would improve employees' behavior related to different dimensions like job performance (Walumbwa et al., 2009), improving employee job satisfaction (Khan et al., 2009), organizational commitment (Ekmekçioglu, 2016), organizational productivity (Imran et al., 2015), organizational citizenship behavior (Somech, A., Drach-Zahavy, A. (2004). In previous research, interpersonal justice (Yangin D \& Elma C, 2017) showed positive impact among teachers. Furthermore, How HRMPs moderate the relationship between organizational justice and innovative work behavior of employees? The outcomes of this hypothesis were significant except selection and overall HRMPs. Different HRMPs like selection, Training, compensation, Performance appraisal, and participation were tested. In previous studies its outcomes were seen to be moderating with knowledge absorptive capacity and project performance (Popaitoon.S, Siengthai.S. 2013) and moderation of HRM practices with Entrepreneur Training on Innovation and Small-Medium Firm Performance (Rosli.M.M \&Mahmood., 2013). Finally, How HRMPs mediate the relationship between organizational justice and innovative work behavior of employees? The outcome of this hypothesis was positive and significant when it was testing overall. Different HRMPs like selection, Training, compensation, Performance appraisal, and participation were tested so mediation was not seen in any of the HRMP practices except overall. In previous studies its outcomes were seen to be mediating of HRM Pratices (Riccucci.N, Fuenzalida.J. 2018). 
Global Journal of Human Resource Management

Vol.8, No.1, pp.20-45, February 2020

Published by ECRTD-UK

Print ISSN: 2053-5686(Print), Online ISSN: 2053-5694(Online)

\section{CONCLUSION}

Moderating/mediating effects of HRMPs in organizational justice on innovative work behavior of employees was studied in present research paper. As suggested in literature Justice is very important principle in society. Fundamentally, without justice well-being of employees is quite difficult. In each type of organization; justice has different impact on employees working in organization. Literature supports that distributive (Cohen-Charash \& Spector, 2001) and interactional justice are positively linked with the performance of employees (Iqbal, Rehan, Fatima, \&Nawaz, 2017) and procedural justice is negatively linked as for as performance of employees and satisfaction is concerned (Tim, 1995). Current study showed that distributive justice $(\mathrm{H} 2)$ has insignificant impact on innovative work behavior of employees working in different hotels. Improper distribution of tasks, extra workload and pressure to complete task on urgent basis can be the cause of negative impact on innovative work behavior of employees. This dimension must be considered because for justice; tasks of employees must be equally distributed. Along this Interpersonal justice (H4) has negative impact. That shows there is a big problem of not communication or miss-communication because Karachi is big city and selected hotels have huge share in market that's why everyone is just strictly following rules and there is no concept of being in-formal. Other reason can be leadership style there focus is just on work not on employees' perception. Others dimensions of organizational justice have positive impact.

In moderation scenario Training (H6b), Compensation (H6c), Performance Appraisal (H6d), and Participation (H6e), HRMPs is showing positive impact between organizational justice and innovative work behavior of employees. Hotel industry is very challenging industry so active participation of employees, proper training (before and on the job), benefits for motivational purpose, and trails of employees matters a lot in this industry.

Furthermore, in mediation case overall mediation is seen when it was tested separately no mediation was in any of the HRMP between organization justice and innovative work behavior of employees. Finally, there is need to focus on each employee and great need to change the leadership style. Calm environment is required to work properly. There must not any pressure or workload. Each should be treated in well-mannered and equally because employees are assets for the hotel industry if they will be treated with justice then hotel industry can grow. Well in that case the great responsibility lies on management which ensures that justice with its all dimensions in hotels is implemented. Tasks, Jobs and rewards distribution should be fair and without any discrimination. Procedures and process should be clearly defined. Employee behavior impacts a lot that's why interpersonal communication should be clear and fair. Information sharing must be accurate for taking right decision on right time because in hotels policies change according to the situation so, employees must be well trained to adopt change. Employees must take part actively to achieve targets for that purpose innovative work behavior of employees is highly appreciated. Hotels are trying hard for becoming more competitive because this is the era of technology and innovation so for becoming more competitive employees should be competent, loyal, trust worthy, satisfied and motivated that can only be possible if they are treated in well-mannered and with justice. 
Global Journal of Human Resource Management

Vol.8, No.1, pp.20-45, February 2020

Published by ECRTD-UK

Print ISSN: 2053-5686(Print), Online ISSN: 2053-5694(Online)

\section{Limitations and Future Research Directions}

The data was collected only from hotels located in Karachi which needs further expansion to different cities and countries other than Pakistan to border the scope of the study. Current study is conducted on small sample size which needs to be tested on big sample size. Furthermore, research is required to identify others HRMPs which can play important role for supporting relationship of organizational justice and innovative work behavior. Last but not the least, for this current study only middle and top management of hotels is targeted so there is also need to include the lower management to see the overall impact.

\section{References}

Acquaah, M. (2004). Human factor theory, organizational citizenship behaviors and human resources management practices: An integration of theoretical constructs and suggestions for measuring the human factor. Review of Human Factor Studies, Vol. 10(1), 118-151.

Adams, J, S. (1965) Inequity in social exchange. In L. Berkowitz (Ed.), Advances in experimental social psychology (Vol. 2, pp. 267-299). New York: Academic Press.

Aiken, L, S., \& West, S, G. (1991). Multiple regression: Testing and interpreting interactions. Thousand Oaks, CA: Sage.

Alexander, S., Sinclair, R. R., \& Tetrick, L. E. (1995).The role of organizational justice in defining and maintaining the employment relationship. In L. E. Tetrick \& J. Barling (Eds.), changing employment relations: Behavioral and social perspectives (pp. 61-89).

Alfes, K., Shantz, A., Truss, C. and Soan, E. (2013). 'The Link between Perceived Human Resource Management Practices, Engagement and Employee Behavior: A Moderated Mediation Model'. The International Journal of Human Resource Management 24(2), 330-351

Akram, T., Haider, M.J., Feng, Y.X.,(2016). The Effects of Organizational Justice on the Innovative Work Behavior of Employees: An Empirical Study from China. Innovation 2016, 2, 114-126.

Ambrose, M. L. and Schminke, M. (2003). 'Organization structure as a moderator of the relationship between procedural justice, interactional justice, perceived organizational support, and supervisory trust'. Journal of Applied Psychology, 88, 295-305

Beugelsdijk. (2008). Strategic human resource practices and product innovation. Organization Studies, 29, 821-847.

Bies, R. J., \& Moag, J. F. (1986). Interactional justice: Communication criteria of fairness. In R. J. Lewicki, B. H. Sheppard, \& M. H. Bazerman (Eds.), Research on negotiations in organizations (Vol. 1). Greenwich, CT: JAI Press

Bratton John and Gold Jeffrey (2003) Human Resource Management: Theory and Practice third edition London: Palgrave Macmillan

Bysted, R. \& Jespersen, K. (2012). Exploring managerial mechanism that influence innovative work behaviour: comparing private and public employees. Public Management Review. 16(2). 217-Z

Chao, C. Y., Lin, Y. S., Cheng, Y. L., \& Tseng, Y. C. (2011). Employee innovation, supervisory leadership, organizational justice, and organizational culture in Taiwan's manufacturing industry. African Journal of Business Management, 5(6), 2501-2511 
Global Journal of Human Resource Management

Vol.8, No.1, pp.20-45, February 2020

Published by ECRTD-UK

Print ISSN: 2053-5686(Print), Online ISSN: 2053-5694(Online)

Chen, C. J., \& Huang, J. W. (2009). Strategic human resource practices and innovation performance-The mediating role of knowledge management capacity. Journal of Business Research, 62(1), 104-114.

Choi, J. N. (2010). The effects of human resource development investment and learning practices on innovative performance of organizations. California Digital Library. Retrieved from https://escholarship.org/uc/item/6cw286pv

Chowdhury, S. (2002) The Talent Era : Achieving A High Return On Talent . Financial Times. Prentice Hall. New York.

Chang, S. Gong, Y. and Shum, C. (2011), "Promoting innovation in hospitality companies through human resource management practices", International Journal of Hospitality Management,Vol. 30, pp. 812-818.

Cohen, R. L., \& Greenberg, J. (1982) The justice concept in social psychology. In J. Greenberg \& R. L. Cohen (Eds.), Equity and justice in social behavior (pp. 1-41). New York: Academic Press.

Cohen-Charash, Y., \& Spector, P. E. (2001). The role of justice in organizations: A meta-analysis. Organizational Behavior and Human Decision Processes, 86(2), 278-321.

Conlon, D. E., \& Ross, W. H. (1997). Appearances do count: The effects of outcomes and explanations on disputant fairness judgments and supervisory evaluations. International Journal of Conflict Management, 8, 5-31

Colquitt, J. A. (2001). On the dimensionality of organizational justice: A construct validation of a measure. Journal of Applied Psychology, 86, 386-400

Colquitt, J. A., \& Greenberg, J. (2003). Organizational justice: A fair assessment of the state of the literature. In J. Greenberg (Ed.), Organizational behavior: The state of the science (pp. 165-210). Mahwah, NJ: Lawrence Erlbaum Associates.

Cropanzano, R., Bowen, D. E., \& Gilliland, S. W. (2007). The management of organizational justice. The Academy of Management Perspectives, 21(4), 34-48.

Degoey, P. (2000). "Contagious justice: Exploring the social construction of justice in organizations." Research in Organizational Behavior 22: 51-102.

De Jong, J., \& Den Hartog, D. (2010). Measuring innovative work behaviour. Creativity and Innovation Management, 19(1), 23-36.

De Spiegelaere, S., et al. (2014). On the relation of job insecurity, job autonomy, innovative work behaviour and the mediating effect of work engagement. Creativity and Innovation Management, 23(3), 318-330

Dittmer, P. R. (2001). Dimensions of the Hospitality Industry (3rd edition). New York, NY: John Wiley \& Sons.

Dorenbosch, L., Van Engen, M. L., \& Verhagen, M. (2005). On-the-job Innovation: the impact of job design and human resource management through production ownership. Creativity and Innovation Management. 14(2). 129-141.

Elovainio, M., Kivima“ki, M., \& Helkama, K. (2001). Organizational justice evaluations, job control, and occupational strain. Journal of Applied Psychology, 86, 418- 424.

Ekmekçioglu.E.B, SÖKMEN.A (2016). The Mediating Role of Job Satisfaction on the Relationship Between Perceived Organizational Support and Affective Commitment: A Research in the Public Sector, Journal of Business Research-Türk. 
Global Journal of Human Resource Management

Vol.8, No.1, pp.20-45, February 2020

Published by ECRTD-UK

Print ISSN: 2053-5686(Print), Online ISSN: 2053-5694(Online)

Farr, F. and Ford, C. (1990) Individual Innovation. In: West, M.A. and Farr, J.L., Eds., Innovation and Creativity at Work: Psychological and Organisational Strategies, Wiley, Chichester.

Fernandez, S., \& Pitts, D. W. (2011) Understanding employee motivation to innovate: evidence from front line employees in United States Federal Agencies. The Australian Journal of Public Administration. 70(2). 202-222.

Fox, S., Spector, P. E., \& Miles, D. (2001). Counterproductive work behaviour (CWB) in response to job stressors and organizational justice: Some mediator and moderator tests for autonomy and emotions. Journal of Vocational Behavior, 59, 291-309.

Folger, R. and Cropanzano, R. (1998) Organizational Justice and Human Resource Management. Sage, Thousand Oaks

Foss, N. J., Laursen, K., and Pedersen, T. (2011). Linking Customer Interaction and Innovation: The Mediating Role of New Organizational Practices. Organization Science, 22(4): 980999.

George JM, Brief AP (1992) Feeling good-doing good: A conceptual analysis of the mood at workorganizational spontaneity relationship. Psychological Bulletin 112: 310-329.

Greenberg, J. (1987). A taxonomy of organizational justice theories. Academy of Management Review, 12(1), 9-22.

Greenberg, J (1990). Organizational justice: yesterday, today and tomorrow, Journal of Management, 16:399-432.

Güllüce C.A, \& Kahyaoğlu. M. (2016). Correlation between Organizational Justice Perception and Organizational Identification: A Case Study in the Hotels of the Urartu Culture and Tourism Development Region. International Journal of Business Administration, Vol. 7, No. 3; 2016

H.G. Osburn, (2000). Coefficient Alpha and Related Internal Consistency Reliability Coefficients, American Psychology Association, Inc, 343-335.

Hendry, C. and Pettigrew, A. (1990) "Human resource management: an agenda for the 1990s", International Journal of Human Resource Management, Vol. 1' No. 1, pp. 17-43

Hosain, M. S. (2015). Adoption of proper HRM practices: A technique for retaining employees and increasing firm performance? Scholar Journal of Business and Social Science, 1(1), $1-14$.

Homans, G. C. (1961) Social behavior: Its elementary forms. New York: Harcourt, Brace, and World.

Hulin, c.L. (1991). Adaptation, persistence, and commitment in organizations. In M.D. Dunnette \& L.M. Hough (Eds.), Handbook of industrial and organizational psychology (2nd ed., Vol. 2, pp. 445-505).

HSU, J., L., \& Wang, J., H. (2015). Exploring the effects of organizational justice on employees' innovative behavior in hospitality industry: From the aspect of organizational support. Revista de cercetare i intervenie social, 49, 113-126.

Imran et al. (2015) " Impact of Organizational Justice, Job Security and Job satisfaction on Organizational Productivity," Journal of Economics, Business and Management vol. 3, no. 9, pp. 840-845, 2015

Iqbal MZ, Rehan M, Fatima A, Nawab S. (2017). The Impact of Organizational Justice on Employee Performance in Public Sector Organization of Pakistan. International Journal Econ Management Sci 6: 431. 
Global Journal of Human Resource Management

Vol.8, No.1, pp.20-45, February 2020

Published by $E C R T D-U K$

Print ISSN: 2053-5686(Print), Online ISSN: 2053-5694(Online)

Jackson et al., (2014 ). Aspirational framework for strategic human resource management, Academy of Management Annals, 8 (2014), pp. 1-56

Janssen, O. (2000), Job demands, perceptions of effort-reward fairness, and innovative work behavior, Journal of Occupational and organizational psychology, 73, 287-302

Jimenez, D.J. and Valle, R.S. (2008), “Could HRM support organizational innovation?”, The International Journal of Human Resource Management, Vol. 19, No.7, pp. 1208-122.

Jiang, J., Wang, S., \& Zhao S. (2012). Does HRM facilitate employee creativity and organizational innovation. A study of Chinese firms. The International Journal of Human Resource Management. 23(19). 4025-4047.

Jones, D. A., \& Skarlicki, D. P. (2013). How perceptions of fairness can change: A dynamic model of organizational justice. Organizational Psychology Review, 3(2), 138-160.

Kanter, R. M. (1988). When a Thousand Flowers Bloom: Structural, Collective, and Social Conditions for Innovation in Organization\|; Research in Organizational Behavior, Vol. 10, pp $169-221$.

Kaul, A., \& Luo, J. (2016). An Economic Case for CSR: The Comparative Efficiency of For-Profit Firms in Meeting Consumer Demand for Social Goods.

Kalay F, (2016). The Impact of Organizational Justice on Employee Performance: A Survey in Turkey and Turkish Context, International Journal of Human Resource Studies. Vol. 6, No. 1

Kelloway, E. K., Francis, L., \& Montgomery, J. (2005).Management of occupational health and safety, ( $3^{\text {rd }}$ ed).Scarborough, ON: Nelson

Khan, A.S., Khan, S., Nawaz, A. \& Khan, N. (2009). Demographic impact on the job satisfaction of the District Executive Offices in local Government, NWFP, Pakistan, Gomal University Journal Research: pp. 1-19.

Kim, Y., \& Lee, B., G. (2013). An analysis for the mediating effect of organizational justice on the performance in the virtual organization. International journal of software engineering and $\mathrm{m}$ /effects-oforganizational-justice-onthe-innovative-workbehavior-ofemployees.html its applications, 201-210

Korczynski, M. (2002), Human Resource Management in Service Work, Palgrave Macmillan, New York, NY

Konovsky, M. A., \& Pugh, S. D. (1994).Citizenship behavior and social exchange. Academy of Management Journal, 37, 656-669

Laforet, S. (2013). Organizational innovation outcomes in SMEs: Effects of age, size, and sector. Journal of World business, 48(4), 490-502.

Laursen, K., and Foss, N. J. (2003). New human resource management practices, complementarities and the impact on innovation performance. Cambridge Journal of economics, 27, No.2, pp. 243-263.

Leong, C. T., \&Rasli, A. (2014).The Relationship between innovative work behaviors on work role performance: An empirical study. Procedia-Social and Behavioral Sciences 129, 592 $-600$

Leventhal, G. S. (1980). What should be done with equity theory? New approaches to the study of fairness in social relationships. In K. Gergen, M. Greenberg, \& R. Willis (Eds.), Social exchange: Advances in theory and research (pp. 27-55). New York: Plenum. 
Global Journal of Human Resource Management

Vol.8, No.1, pp.20-45, February 2020

Published by ECRTD-UK

Print ISSN: 2053-5686(Print), Online ISSN: 2053-5694(Online)

Leventhal, G. S., Karuza, J., \& Fry, W. R. (1980). Beyond fairness: A theory of allocation preferences. In G. Mikula (Ed.), Justice and social interaction (pp. 167-218). New York: Springer-Verlag.

McCain C. S, Henry Tsai H, Bellino N, 2010). Organizational justice,employees' ethical behavior, and job satisfaction in the casino industry, International Journal of Contemporary Hospitality Management, Vol. 22 Iss 7 pp. $992-1009$

Mondy, R. W., Noe, R. M. (2005). Human Resource Management, 9th ed. Pearson Education, Inc Momeni, M., Ebrahimpour, D., H., \& Ajirloo, D., M.,B. (2014). Surveying the impact of inferential organizational justice on innovative work behavior. Singaporean journal of business economics and management studies, 2 (9)

Mumford. M. D., Zaccaro, S. J., Harding, F. D., Jacobs, T. O., \& Fleishman, E. A. (2000).Leadership skills for a changing world: Solving complex social problems. Leadership Quarterly 11(1), 11-35

Niehoff, B. P., \& Moorman, R. H. (1993). Justice as a mediator of the relationship between methods of monitoring and organizational citizenship behavior. Academy of Management Journal, 36, 527-556

Pablo Z, Jyh-Ming T, 2017). "Employees' justice perceptions as a factor influencing successful outsourcing in the hospitality industry", International Journal of Contemporary Hospitality Management, Vol. 29

Pareek \& Rao , 2007)., 'Designing and managing human resource system', Oxford and IBM Publishing Co. Ltd., New Delhi, pp. 572-573.

Pelit, E., \& Bozdoğan, I. (2014). The Effect of Perception of Organizational Justice on Burnout Level of Employees:A Study on Five Star Hotels in Kemer District. Journal of Business Studies, 6(2), 37-66.

Pfeffer, J. and Langton, N. (1993)."The Effect of Wage Dispersion on Satisfaction, Productivity, and Working Collaboratively: Evidence from College and University Faculty", Administrative Science Quarterly, Vol. 38, pp. 382-407

Popaitoon.S, Siengthai.S., (2013). The moderating effect of human resource management practices on the relationship between knowledge absorptive capacity and project performance in project-oriented companies. International Journal of Project Management, p.13

Prieto, M. P., \& Perez-Santana, M. P. (2014). Managing innovative work behavior: the role of human resource practices. Personnel Review. 43(2). 184-208. doi:10.1108/PR-11-20120199

Riccucci.N, Fuenzalida.J., 2018). The Effects of Politicization on Performance: The Mediating Role of HRM Practices. Review of Public Personnel Administration.1-26

Rosli.M.M \&Mahmood., 2013). Moderating Effects of Human Resource Management Practices and Entrepreneur Training on Innovation and Small-Medium Firm Performance. Journal of Management and Strategy, Vol. 4, No. 2

Scott, S. G., \& Bruce, R. A. (1994). Determinants of innovative behavior: A path model of individual innovation in the workplace. Academy of Management Journal, 37(3), 580-607.

Silva. H. M. S. V \& Madhumali. K. P. W. C.,( 2014). Organizational Justice and Organizational Citizenship Behavior: A Study of Public Sector Organizations in Western Province, Sri Lanka. Kelaniya Journal of Human Resource Management Volume 09 
Global Journal of Human Resource Management

Vol.8, No.1, pp.20-45, February 2020

Published by ECRTD-UK

Print ISSN: 2053-5686(Print), Online ISSN: 2053-5694(Online)

Skarlicki, D.P. and Folger, R. (1997), "Retaliation in the workplace: the roles of distributive, procedural, and interactional justice”, Journal of Applied Psychology, Vol. 82 No. 3, pp. 434-443.

Somech, A., Drach-Zahavy, A. (2004).Exploring organizational citizenship behavior from an organizational perspective: the relationship between organizational learning and organizational citizenship behavior. Journal of Occupational and Organizational Psychology, Vol: 77, Issue: 3, pp: 281-298. Accounting Research, Vol. 7, pp. 122-47.

Tan, C. L., and Nasurdin, A. M. (2011). Human resource management practices and organizational innovation: assessing the mediating role of knowledge management effectiveness. Electronic Journal of Knowledge Management, Vol.9, No.2, pp. 155-167.

Tepper, B. J. (2001). Health consequences of organizational injustice: Tests of main and interactive effects. Organizational Behavior and Human Decision Processes, 86, 197-215.

Terry, D. J., \& Thibaut, J., \& Walker, L. (1975). Procedural justice: A psychological analysis. Hillsdale, NJ: Erlbaum.

Tessema, M., \& Soeters, J. (2006). Challenges and prospects of HRM in developing countries: testing the HRM-performance link in Eritrean civil service. International Journal of Human Resource Management, 86-105

Timetric. (2013). The Global luxury hotels market: Key trends and opportunities to 2017, Retrieved 11/2013, from http://www.prweb.com/releases/2013/11/prweb11358955.htm

Tim, L. (1995), "Fairness as an antecedent to participative budgeting: examining the effects of distributive justice, procedural justice and referent cognitions on satisfaction and performance", Journal of Management

Upasna A. Agarwal, (2014) "Linking justice, trust and innovative work behaviour to work engagement", Personnel Review, Vol. 43 Issue: 1, pp.41-73.

Walumbwa, F. O., Cropanzano, R., \& Hartnell, C. A. (2009). Organizational justice, voluntary learning behavior, and job performance: A test of the mediating effects of identification and leader-member exchange. Journal of Organizational Behavior, 30, 1103-1126

Wright, P.M. \& Snell, S.A. 1991. Toward an integrative view of strategic human resource management. Human Resource Management Review, 1, 203-225.

Yiğitol.B and Balaban.O. (2018). Relationship between Organizational Justice and Employee Satisfaction: Evaluation of Human Resources Functions,EconWorld2018@Lisbon

Yuan F., Woodman R.W.: Innovative behavior in the workplace: the role of performance and image outcome expectations. Academy of Management Journal, Vol. 53, No. 2, 201

Yangin D \& Elma C( 2017). The Relationship among Interactional Justice, Manager Trust and Teachers' Organizational Silence Behavior. Universal Journal of Educational Research 5(3): 325-333

Zapata-Phelan, C. P., et al., (2008). Procedural justice, interactional justice, and task performance: Organizational Behavior and Human Decision Processes. 